\title{
Measurement and Assessment of the Developmental Status of Islamic University Governance: Indonesia Perspective
}

\author{
Hani Werdi Apriyanti* \\ Department of Accounting, Faculty of Economics, UNISSULA (Sultan Agung Islamic University), Kaligawe Raya, \\ Genuk, Semarang, Indonesia \\ *Correspondence: hani.apriyanti@unissula.ac.id (Hani Werdi Apriyanti, Lecturer, Dept. of Accounting, UNISSULA, \\ Indonesia)
}

\begin{abstract}
Islamic Private Universities are currently faced increasingly competition with other University. Therefore, Islamic Private Universities needs to implement Good Governance in providing services to the community. There is a need in developing indicators to measure the achievement of the governance process. Islamic Private Universities can differentiate services that cannot be obtained at other University by strengthening and applying Islamic aspects in University Governance. This study aims to develop indicators of Islamic University Governance for Islamic Private Universities through three stages, Focus Group Discussion (FGD), questionnaire, and interview. This stage is carried out to obtain expert opinion and summarize the indicators and weighting of the indicators. Techniques used to analyze data based on the stages of research that have been carried out, 8 dimensions of Islamic university governance measurements developed into 35 indicators, namely 6 indicators for transparency dimensions, 10 indicators for accountability dimensions, 6 indicators for responsibility, 4 indicators for independence, 2 indicators for fairness, 1 indicator for effectiveness and efficiency, and 1 indicator for non-profit.
\end{abstract}

Keywords: Measurement, Governance, Islamic Private Universities, Islamic value, and Assessment.

\section{INTRODUCTION:}

Islamic Private Universities is one of the private universities that develop science and technology for more than 70 percent of Indonesian students (Elfindri, 2016). This is a great potential for Islamic Private Universities to develop knowledge, innovation and technology. To generate and develop knowledge, various methods are needed to make Islamic Private Universities management work properly. The concept of governance for private universities (Good University Governance) provided by the Directorate General of Higher Education must be implemented by Islamic Private Universities by increasing the fulfillment of Islamic values in each of its principles. Islamic Private Universities needs to take advantage of student market opportunities by offering different performance differentiations from other private universities. Therefore, the implementation of good university governance in private Islamic universities must be in line with the Islamic values. Good governance encourages public trust in Islamic Private Universities (Sumarni, 2009).

The majority of Indonesians who are Muslim offer Islamic Private Universities the opportunity to expand market to the community (Dirwan, 2012). Islamic Private Universities needs to develop its education with Islamic values, including the concept of good university governance, which is in line with Islamic principles and values (Gazi, 2020). This advantage further enhances the bargaining power of Islamic Private Universities, which is different from other universities (Imran et al., 2011). 
To measure and evaluate the implementation of University governance in Islamic Private Universities, comprehensive and reliable indicators are needed so that the improvement process can be measured (Quyên, 2014; Jony et al., 2019). This study aims to develop indicators to measure the implementation of Islamic University governance at Islamic Private Universities. Indicators are developed to measure the implementation of Islamic university governance. This study aims to offer the concept of governance measurement in Islamic universities. This indicator needed by Islamic Private Universities to assess the achievement level of Islamic university governance implementation to meet public expectations (service quality).

\section{Literature Review}

Good University Governance (GUG) is a university management concept in managing its resources. Good University Governance (GUG) is established to create an accountability university (DIKTI, 2014). According to Indonesian Ministry of Education (DIKTI) there are eight principles in the GUG, namely transparency, accountability, responsibility, independence, fairness, quality assurance and relevance, effectiveness and efficiency, and not-forprofit. University must apply the principles of Good University Governance in managing theirs resources (Media Indonesia, 2010).

Transparency in the management of institutions is carried out through a check and balance mechanism in the management of institutions (Siri, 2015). This function can be carried out by the Academic Senate both at the university level and at the Faculty level who acts to carry out the control function of the Chancellor and the Dean. The Academic Senate chosen and representing the lecturer, carries out the function of supervising the Chancellor and the Dean.

Accountability is closely related to the mission of the University that carries out the mandate of the government, the community and the governing body to organize education (Sita et al., 2017). The mandate carried out by the institution is carried out with the permission to establish a University and department from the Ministry of Research and Technology. In addition, accountability is closely related to financial management. Accountability requires universities to be accountable in managing finances.
University must be able to manage the use of funds for its operations. To maintain accountability, University financial statements needs to be audited by public accountants and disclosed to the public (Islam and Alam, 2019).

Responsibility and Fairness is applied in terms of enforcing regulations in University. University must apply this principle in the distribution of positions, functions, tasks, responsibilities and authorities of each element of the organization. University must have job description for each position and standard operating procedures (SOP). Other responses in terms of appointing employees based on competence and track records and the implementation of an appropriate merit system (incentives and dis-incentives) for employees.

University through an internal quality assurance system with Minimum Standards and external quality assurance through BAN-PT accreditation for the University Level and Study Programs at the Faculty Level. The quality assurance process can be carried out through various efforts to improve the quality of lecture, student's feedback, alumni networking, and improve the quality of evaluation process through a survey of services that have been provided by the institution to stakeholders.

Effectiveness and efficiency is implemented through a planning system, both long term and short term (annually). University strategic planning including achieving Vision and Mission for five years or ten years can lead to the effectiveness and efficiency of the University management. This plan is a reference for University in carrying out management activities, and can be used as a means of evaluating the achievement of each stage of the implementation of the program. Finally, the principle that must not be eradicated is non-profit. Islamic Private University in accordance with its mandate and role to run nonprofit activities, so the budget that has been collected must be utilized to improve the quality and education development.

The GUG principles mandated by the Directorate of Higher Education must be adjusted to the Islamic Mission Vision of Islamic Private University by exploring and applying principles that are in accordance with Islamic values. The GUG principles in accordance with these Islamic values can be used 
by Islamic Private University to conduct a process of evaluating the performance of University in providing services to the community as well as measuring the level of Islamic Private University compliance with sharia principles

\section{Theoretical Framework}

Good University Governance (GUG) is the key success factor in achieving university competitive advantages (Ali et al., 2016). Implementing Good University Governance (GUG) principles, can improve the University quality in educational and research program. Islamic Private University has to fulfil the Islamic principle in the implementation of Good University Governance (GUG) which in line with the Vision and Mission of University. The Vision and Mission of Islamic Private University in addition to carrying out the mandate of the establishment of University which is as a non-profit institution, based on Islamic values.

Islamic values implementation is not only on a conceptual level, but also must be implemented in the university management. University management activities must be carried out in a way that is good and right in accordance with the direction exemplified by the Prophet Muhammad, as a logical consequence of monotheism. This implementation should be implemented in the organization of the Human Resources, and other activities. Good governance must be carried out by good quality human resources by imitating the qualities of the Prophet Muhammad, namely Shiddiq, trustworthy (amanah), Fatonah, and mutual information (Tabligh). The concept of Good University Governance (GUG) applied to Islamic Private University has more value and becomes an Islamic University Governance (GUG). Confirmation of this identity is something that is very important, which distinguishes Islamic Private University with others.

The principles developed as indicators in measuring Good University Governance in this study, namely Transparency (Tabayun), Accountability, Responsibility, independence, fairness, quality assurance and relevance, effectiveness and efficiency, Non-profit, and leadership. Transparency or Tabayun with the operational definition of information disclosure to stakeholders which is translated into activities that leads to the provision of stakeholder information.

UniversePG I www.universepg.com
The mission of Islamic Private University that carries out the mandate from the government, the community and the organizing body to organize education requires Islamic Private University to be accountable in managing its resources. University is morally and spiritually responsible for all the tri dharma activities. The principle of accountability in this study has two dimensions, namely the vertical dimension and horizontally to other stakeholders. University must be responsible for the resources managed, as a form of responsibility to stakeholders. The institutions must treat stakeholders fairly in accordance with their functions and roles. This principle will encourage a balanced or tawazun so as to minimize conflicts of interest between the foundation and the university and other parties involved. The application of these values can be used as an indicator of the principles of independence and fairness.

Islamic Private University is not an institution or profit organization that is concerned with earning profit by ignoring compliance with Sharia aspects (Fatin et al., 2017). In supporting the independence of funding, Islamic Private University can run a business unit with the principle of non-profit, that the main goal is not just profit, so that in the effort to achieve profit in accordance with the Islamic principle.

\section{METHODHOLOGY:}

This study was designed using quantitative and qualitative approaches using three stages in the formulation of indicators proposed by the researcher. In the first stage, researchers formulate indicators to measure the implementation of good university governance. These indicators are obtained through a model proposed by the researcher through a comparative study of concepts required by regulations with Corporate Governance theory and the basis in the Qur'an and Hadith. Dimensions that have been compiled as indicators are discussed through Focus Group Discussion by researchers at the First research stage. Dimensions that have been compiled will be tested through a questionnaire to determine the weight of importance for each indicator.

Questioners were distributed to five Islamic Private University in Central Java, with 10 participants in each session. Sample was determined based on the 
criteria of the source of the informant who has the authority in implementing University governance, including 3 University Leaders, 3 Faculty Leaders, and 4 departments in the University. Stages of interviews with stakeholders and the number of head of department at the Islamic Private University in Central Java, as well as other stakeholders, such as lecturers and students, were conducted to maintain the validity of the indicators. The model that has been prepared by the researcher will be retested at the second stage of the study. The testing of this model is carried out to measure the implementation of indicators in University Governance. In the second stage is carried out to see the relevance of indicators that have been prepared previously in the management of private Islamic Private University. The validity of the indicators in this study was tested through the FGD process, and the testing of the model for the implementation of indicators at the expert interview stage. The research output in this second stage, is a measurement model or indicator that can be used to measure Islamic University Governance in University.

\section{Indicators and Operational Definitions -} University Governance in Islamic perspective can be defined as a set of management to direct, manage, and control institutions with governance structures that can protect the interests of all stakeholders, enable the achievement of institutional goals, implement institutional responsibilities, and must be in accordance with Sharia provisions (Alam and Ziaul, 2006). The principle in Islamic University Governance that is proposed is a model based on maslahah to protect all parties involved in the management of the institution. The indicators proposed in this study and which will be tested in the second stage is presented in the following Table 1.

Table 1: Operational definition, and dimension dan Islamic University governance indicator.

\begin{tabular}{|c|c|c|}
\hline Indicator & Definition & Implication \\
\hline \multirow{3}{*}{ Transparancy } & \multirow{3}{*}{$\begin{array}{l}\text { The understanding } \\
\text { level of operational } \\
\text { activities by the } \\
\text { stakeholders }\end{array}$} & Check and balances as a mean of "Tabayun." \\
\hline & & $\begin{array}{l}\text { Academic senate in University dan faculty level hold the function control } \\
\text { to the rector and dean with amanah. }\end{array}$ \\
\hline & & Vision Mission of the University based on Islamic value. \\
\hline \multirow{8}{*}{ Accountability } & \multirow{8}{*}{$\begin{array}{l}\text { University mission } \\
\text { which form of the } \\
\text { government, society } \\
\text { and foundation } \\
\text { mandate to held the } \\
\text { education }\end{array}$} & $\begin{array}{l}\text { Disclosure of Financial statement including financial and non financial } \\
\text { periodically, accurately, comparable, easily access to the stakeholders. }\end{array}$ \\
\hline & & $\begin{array}{l}\text { University operates the vision and mission in accordance with the } \\
\text { permission from the Ministry of Education. }\end{array}$ \\
\hline & & The Education suit with the requirements from the government. \\
\hline & & University funding reported annually. \\
\hline & & Financial report has been audit by the Public Accountant. \\
\hline & & $\begin{array}{l}\text { University take responsibility morally and spiritually of the" tridharma." } \\
\text { activity }\end{array}$ \\
\hline & & $\begin{array}{l}\text { Education process and result reported to the ministry of education and the } \\
\text { foundation (yayasan) in annual report. }\end{array}$ \\
\hline & & The summary of annual report disclosed annually to the society. \\
\hline \multirow[t]{2}{*}{ Responsibility } & \multirow{2}{*}{$\begin{array}{l}\text { Responsibility } \\
\text { principle to the } \\
\text { university resource }\end{array}$} & $\begin{array}{l}\text { The personal in the university take the responsibility of the activities } \\
\text { based on the job description. }\end{array}$ \\
\hline & & Lecturer obeys the University norm and ethic. \\
\hline
\end{tabular}




\begin{tabular}{|c|c|c|}
\hline & & $\begin{array}{l}\text { The job and function distribution of the organization element has been } \\
\text { done effectively. }\end{array}$ \\
\hline & & $\begin{array}{l}\text { The University built and has standard operating procedure (SOP) for each } \\
\text { activity. }\end{array}$ \\
\hline & & Employee recruitment and hiring based on track record and competition. \\
\hline & & The merit system (insentif dan disinsentif) properly for the employee. \\
\hline \multirow{3}{*}{ Independency } & \multirow{3}{*}{$\begin{array}{l}\text { Freedom from the } \\
\text { control or influence } \\
\text { of other stakeholders }\end{array}$} & There is no conflict of interest between the foundation and University. \\
\hline & & Decision making execute independently. \\
\hline & & $\begin{array}{l}\text { Foundation gives the authority to the university to hold the tridharma } \\
\text { activity (education, research, and community service). }\end{array}$ \\
\hline \multirow{2}{*}{ Fairness } & \multirow{2}{*}{$\begin{array}{l}\text { Fairness in the treat- } \\
\text { ment to all terhadap } \\
\text { stakeholder }\end{array}$} & $\begin{array}{l}\text { University treats the students, society, lecturer, academic staff and } \\
\text { foundation fairly. }\end{array}$ \\
\hline & & Quality assurance and relevancy. \\
\hline \multirow{4}{*}{$\begin{array}{l}\text { Quality assurance } \\
\text { and relevancy }\end{array}$} & \multirow{4}{*}{$\begin{array}{l}\text { Principle of effec- } \\
\text { tiveness on the inter- } \\
\text { nal control }\end{array}$} & There is quality assurance of internal control. \\
\hline & & There is treasure study for the university. \\
\hline & & Alumni take part in university development. \\
\hline & & Survey to the service has been done. \\
\hline $\begin{array}{l}\text { Effectiveness and } \\
\text { efficiency }\end{array}$ & $\begin{array}{l}\text { Effective and efeffi- } \\
\text { cient planning }\end{array}$ & University has planning system (long term and short term). \\
\hline Nirlaba & Non profit oriented & Budget utilized to increase the quality and develop the university. \\
\hline
\end{tabular}

Source: Data processed, 2019

Data Analysis Techniques - Researchers use qualitative and quantitative analysis. Quantitative analysis is used to help solve the problems with tools related to statistics and mathematics so that the decisions made can be justified. Quantitative data analysis by collecting existing data then processing it and presenting it in the form of tables, graphs, and analysis so that conclusions can be drawn as a basis for decision making. The researcher use quantitative analysis, namely non-parametric statistics to measure the implementation of governance indicators at PTIS, testing the models that have been prepared.

\section{RESULTS AND FINDINGS:}

Development of Indicators - The development of indicators is based on a comprehensive review of the theoretical concepts of Good University Governance and the practical implications of Islamic university governance in Islamic Private University. This method is used to identify the dimensions of Islamic
University Governance, develop constructs, and identify indicators that are developed. Based on the stages of research previously, seven dimensions of Islamic University Governance were obtained, namely Transparency, accountability, responsibility, independence, fairness, quality assurance and relevance, effectiveness and efficiency, and not-forprofit. Transparency is related to the need for stakeholder information on the activities of university operations. Transparency is the level at which University operational activities can be accepted and understood by stakeholders. Accountability is related to the implementation of the University mission which carries out the mandate of the government, the community and the governing body (Yayasan) to organize Education.

Accountability is the level of responsibility towards stakeholders. Whereas; Responsibility relates to institutional responsibility to the resources that are managed. Independence relates to the institution's 
attitude or freedom from the control or influence of the stakeholders. Quality Assurance and Relevance are principles in the effectiveness of University internal control. Effectiveness and efficiency related to the activities of Islamic Private Universities in carrying out effective and efficient planning functions. Non-profit is related to the function of Islamic private University as an educational institution that is not profit oriented and prioritizes the achievement of profit in its operational activities. Twenty-nine indicators were developed and grouped into eight dimensions, namely five indicators for Transparency, eight indicators for accountability, six indicators for responsibility, and three indicators for independence. One indicator for fairness, one indicator for quality assurance and relevance, five indicators for effectiveness and efficiency, one indicator for nonprofit.

Informants Grouping - Sources or informants are grouped into groups of informants who have deeper knowledge about the concept and implementation of Islamic university governance based on the practical experience as holders of power in university, namely structural position both at university and faculty levels, lecturers who have research in corporate governance, lecturers usually as part of a university that can provide input because lecturers as users and business process practitioners in university. Recommendations from researchers who have a research focus on corporate governance also become an important part in building indicators of Islamic university governance. Characteristics of Informants are presented in Table 2.

Table 2: Informants Groups

\begin{tabular}{|l|c|c|}
\hline Position & Number & Presentation \\
\hline $\begin{array}{l}\text { Structural position in the } \\
\text { University or faculty } \\
\text { level }\end{array}$ & 19 & $42 \%$ \\
\hline Lecturer & 24 & $53 \%$ \\
\hline $\begin{array}{l}\text { Expert in Corporate } \\
\text { Governance }\end{array}$ & 2 & $5 \%$ \\
\hline Amount & 45 & $100 \%$ \\
\hline
\end{tabular}

Source: Data Processed, 2019

Data Collection and Analysis - In the first stage, asking questions online is done and addressed to lecturers who are ordinary lecturers. Submission of questions to lecturers is conducted to obtain input from service users and also lecturer who conduct the tri dharma activities as the main activity of private Islamic private University. In the second stage of asking questions online, a face-to-face meeting with campus structural position and researchers in the field of corporate governance was held to discuss the proposed indicators, namely related to the definition of each dimension developed. Informants were asked to give assessment weights related to the importance of indicators with rating weights from 0 to 4 (not important, not important, important enough, and very important).

Indicators and Construct - Adjustment of indicators from the results of discussions with researchers, and structural position, the campus carried out in the second stage. Namely: for the dimension of transparency added accuracy indicators in providing information. The addition of this indicator by the researcher (two informant sources) is based on Surah Al Baqarah: 22 regarding the order to provide information both financially and nonfinancially to the stakeholders. The accountability dimension that has been proposed at the previous research stage only measures accountability horizontally, relating to the fulfillment of the mission of the University that carries out the mandate of the community, the Government and the University. Therefore based on the results of discussions with informants, an overview and additions are obtained related to the concept of Islam in accountability that should also be measured, namely vertical accountability.

Vertical accountability emphasizes that Islamic private university carry out the responsibilities written in the Vision and Mission as a form of responsibility to Allah. Vision and Mission reflected in the Islamic world view used by Islamic universities. There are no additional indicators for the dimension of responsibility, but only the basic reinforcement used, namely Surat al Anfal: 27 that each individual must be responsible for the trustworthiness of the resources managed. The independent dimension in the second stage of the study experienced the addition of indicators. The addition of this indicator is based on the adjustment of the independent dimension in the perspective of Islam, namely the indicator of the consistency of impartiality only to the stakeholders. 
Table 3: New Indicator and Dimension

\begin{tabular}{|c|c|c|c|}
\hline Dimension & Operational Definition & Indicator proposed in stage-I & Indicator adding \\
\hline Transparency & $\begin{array}{l}\text { The understanding level } \\
\text { of operational activities } \\
\text { by the stakeholders. }\end{array}$ & $\begin{array}{l}\text { - Check and balances as a mean of } \\
\text { Tabayun. } \\
\text { - Academic senate in University dan } \\
\text { faculty level hold the function } \\
\text { control to the rector and dean with } \\
\text { amanah. } \\
\text { - Vision Mission of the University } \\
\text { based on Islamic value. }\end{array}$ & $\begin{array}{l}\text { Accuracy in giving the } \\
\text { information to the } \\
\text { stakeholders. }\end{array}$ \\
\hline Accountability & $\begin{array}{l}\text { University Responsibil- } \\
\text { ity in performing the } \\
\text { vision and mission from } \\
\text { Allah (Vertical } \\
\text { accountability) and } \\
\text { government, foundation, } \\
\text { society in educational } \\
\text { activities (Horizontal } \\
\text { accountability) }\end{array}$ & $\begin{array}{l}\text { Horizontal Accountability } \\
\text { - Disclosure of Financial statement } \\
\text { including financial and non- } \\
\text { financial periodically, accurately, } \\
\text { comparable, easily access to the } \\
\text { stakeholders. } \\
\text { University operates the vision and } \\
\text { mission in accordance with the } \\
\text { permission from the Ministry of } \\
\text { Education. } \\
\text { The Education suit with the } \\
\text { requirements from the govern- } \\
\text { ment. } \\
\text { University funding reported } \\
\text { annually. } \\
\text { Financial report has been audit by } \\
\text { the Public Accountant. } \\
\text { University take responsibility } \\
\text { morally and spiritually of the" } \\
\text { tridharma" activity. } \\
\text { Education process and result } \\
\text { reported to the ministry of } \\
\text { ucation and the foundation } \\
\text { (yayasan) in annual report. } \\
\text { The summary of annual report } \\
\text { disclosed annually to the society. } \\
\text { Vertical Accountability } \\
\text { University responsible morally } \\
\text { and spiritually if tridharma } \\
\text { activity. }\end{array}$ & $\begin{array}{l}\text { Vertical Accountability: } \\
\text { - University takes the } \\
\text { responsibility as written in } \\
\text { Vision and mission } \\
\text { statement as a form of } \\
\text { responsibility to Allah. } \\
\text { - Vision and Mission } \\
\text { describe Islamic world } \\
\text { view hold by the university. }\end{array}$ \\
\hline Responsibility & $\begin{array}{l}\text { Principles of responsi- } \\
\text { bility of the resource } \\
\text { manage by the } \\
\text { University. }\end{array}$ & $\begin{array}{l}\text { - Person in the university take the } \\
\text { responsibility of all the activities } \\
\text { in line with the standard operating } \\
\text { procedure set by the university. } \\
\text { - } \quad \text { Lecturers obey the university } \\
\text { norms and ethics. } \\
\text { - The job and function distribution } \\
\text { of the organization element has } \\
\text { been done effectively. } \\
\text { The University built and has } \\
\text { standard operating procedure } \\
\text { (SOP) for each activity. } \\
\text { Employee recruitment and hiring } \\
\text { based on track record and } \\
\text { competition. } \\
\text { The merit system (insentif and } \\
\text { dis-insentif) properly for the } \\
\text { employee. }\end{array}$ & \\
\hline
\end{tabular}




\begin{tabular}{|l|l|l|l|}
\hline Independency & $\begin{array}{l}\text { Freedom from the } \\
\text { control or influence of } \\
\text { other stakeholders. }\end{array}$ & $\begin{array}{l}\text { There is no conflict of interest } \\
\text { between the foundation and } \\
\text { University. } \\
\text { Decision making execute } \\
\text { independently. }\end{array}$ & $\begin{array}{l}\text { University always holds the } \\
\text { Islamic Value Ig: truth } \\
\text { consistently. }\end{array}$ \\
& $\begin{array}{l}\text { Foundation give the authority to } \\
\text { the university to hold the tri- } \\
\text { dharma activity (education, } \\
\text { research, and community service) }\end{array}$ & \\
\hline Fairness & $\begin{array}{l}\text { Fairness in the treatment } \\
\text { to all terhadap } \\
\text { stakeholders. }\end{array}$ & $\begin{array}{l}\text { University treats the students, } \\
\text { society, lecturer, academic staff } \\
\text { and foundation fairly. }\end{array}$ & $\begin{array}{l}\text { University treats the } \\
\text { stakeholders equally. }\end{array}$ \\
\hline
\end{tabular}

Source: Data Processed, 2019

But the consistency to behave and act in accordance with the truth value and the basis for adding indicators for the independence dimension is the letter Fussilat's: 30. Adding indicators for the Fairness dimension is equality treating stakeholders in accordance with Annisa letter 58. Adding indicators based on the results of Focus Group Discussion with research groups and other informants (structural position with knowledge about Islamic university governance) is presented in Table 3 .

Indicator weighting - The affairs of the most important indicators to be implemented and can be indicators that illustrate Islamic university governance are determined based on the number of scores obtained from respondents' answers to the level of importance of each dimension with predetermined indicators.

Table 4: Indicator Weighting

\begin{tabular}{|c|c|c|c|}
\hline Dimension & Average & Median & $\begin{array}{l}\text { Score/ } \\
\text { numbering }\end{array}$ \\
\hline Transparency & 95,2 & 117 & 8 \\
\hline Accountability & 111,3 & 105,5 & 3 \\
\hline Responsibility & 103,5 & 101,5 & 6 \\
\hline Independency & 116,3 & 121 & 1 \\
\hline Fairness & 112 & 112 & 2 \\
\hline $\begin{array}{c}\text { Quality assurance } \\
\text { and relevance }\end{array}$ & 105,7 & 106,5 & 4 \\
\hline $\begin{array}{c}\text { Effectiveness and } \\
\text { efficiency }\end{array}$ & 104 & 104 & 5 \\
\hline Non-profit & 102 & 102 & 7 \\
\hline
\end{tabular}

Source: Data Processed, 2019
The first dimension which is the main and most important indicator in Islamic university governance is independence with the acquisition of an average score of 116. 3, then fairness with an average score of 112, the third important order of Islamic university governance indicators is accountability with the score of 11.3. Quality assurance and relevance are in the order of importance number 4 with a score of 105.7, while effectiveness and efficiency become priority order after quality assurance and relevance to the score 104. Dimensions of responsibility become the 6th priority with a score of 103.5. Based on respondents' answers, the non-profit dimension becomes the 7th priority (score 102), and the transparency dimension becomes the 8 th measurement priority in Islamic University governance.

\section{DISCUSSION:}

In the first stage of the study, the indicators determined for each dimension included important factors and the implementation of Islamic university governance in Islamic Private University. The answer to the high score or to state the level of strongly agreed to the question as an indicator of each dimension with a high level of agreement illustrates the reliability of the indicators used and proposed (Milon, 2019). Present Scenario of Human Resource Management (HRM) Practices in the Life Insurance Companies: Bangladesh Perspective (Shuvro et al., 2020). In general, all dimensions proposed with existing indicators have a high approval rate of above $90 \%$. Results The order of scores for these dimensions indirectly illustrates the level or order of importance of the eight dimensions, with the order of independence, fairness, accountability, quality assurance and relevance, effectiveness and efficiency, responsibility, non-profit, transpar- 
ency being the eighth priority in Islamic University governance.

First: Independence - Islamic Private University which is the source or place of informants is Islamic Private University with a legal entity from the Foundation. The problem faced by Islamic Private University under the Foundation (the Management Agency is the Foundation) is the problem of the difficulty of applying the principle of independence, because of various problems such as the high dependence of university to the Foundations related to funding, Determination of Authority, and resources. Islamic Private University cannot be independent. Therefore, the independence dimension becomes the main priority sequence which is an indicator of the implementation of the Islamic University Governance. Islamic Private University must be able to determine its attitude by not taking sides with one of the stakeholders and be consistent with the value of truth and honesty. As an implementation of Quran Surah Fussilat's 30. Independence is measured by the absence of conflict of interest between the foundation and the university's management in carrying out its roles and responsibilities.

The Foundation has the role and responsibility as a manager of Islamic Private University, while Islamic Private University is an Education unit that carries out the mandate of the Foundation with a Vision and Mission that is in line with the Foundation's Vision and Mission. By fulfilling the responsibilities of each party, they can place themselves in accordance with the position with the specified rights and obligations, so as to minimize conflicts of interest between the two parties. In the management of Islamic Private University with Tri Dharma activities (Education, research, and community service), Islamic Private University must adopt an independent attitude, which is guided by the truth and honesty in every decision-making.

PTIS courage to be guided by honesty and truth will minimize the pressure of various parties. With the value of Truth and honesty carried out by Islamic Private University will have an impact on increasing the trust of the Foundation as a manager of Islamic Private University to give full authority to the University to hold the tri dharma? The improvement of this two-way process, both from the Islamic
Private University and Foundation, will increase the independence of University.

Second: Fairness - Fairness is the second priority indicator that is important to apply in Islamic Private University. Fairness relates to the fairness in every treatment to the stakeholders and also the concept of equality or equality of treatment. Islamic Private University should treat all stakeholders including students, the community, lecturers, academic staff, education staff and foundation administrators fairly and equally. Explanation of fairness in this treatment is more to fair treatment in a fair manner in accordance with the position and position of each stakeholder towards the institution. Equality also means putting things in the same position and adjusting to justice with the portion of each stakeholder. The use of two indicators in the Fairness dimension is derived from the Qur'an Surah Annisa 58 which explains the order to be fair. Based on this Ayat, Islamic Private University must treat stakeholders equally.

This indicator is very important, in the second place, because the problem of unfair treatment is also one of the obstacles for Islamic Private University which management is under the Foundation. The high level of dependence of Islamic Private University on the Foundation as the manager of University, can lead to unfair and unequal treatment of existing stakeholders. Islamic Private University can be motivated to treat the Foundation with more priority (unfair treatment) compared to other stakeholders, because the Foundation is the founder and manager of Islamic Private University which must obtain preferential treatment (traditional culture). Various traditional cultures that is still inherent in the management of Islamic Private University, become problems that must be resolved. Therefore the fairness dimension becomes the second most important priority sequence that can describe Islamic University Governance.

Third: Accountability - The accountability dimension is not less important as an indicator of Islamic University Governance. Islamic Private University with different characteristics from other private universities, with Islamic Values must be able to internalize university responsibilities in carrying out the University Mission as a mandate from God (Allah swt). Islamic Private University's responsibil- 
ity to God as a form of Vertical accountability is the fulfillment of responsibility to God based on the AlQuran surah Albaqarah.

Part of the responsibilities that God commands as a form of responsibility is the fulfillment of information needed by stakeholders. Provision of this information is mandated by the responsibilities given by the government, the community and the governing body to Islamic Private University in organizing Education (Horizontal Accountability). The problem faced by Islamic Private University in general is the low level of accountability to stakeholders, both accountability relating to the provision of financial and non-financial information (Ninik and Ilsa, 2015).

Indicators that can be used to measure the accountability of Islamic private universities are -1) whether or not the disclosure of financial statements that provides both financial information and nonfinancial information on a periodic basis, accurate and easily accessible, and comparable. The qualitative characteristics of the financial statements must be in accordance with the characteristics of the quality of information that should be produced by the institution in accordance with financial reporting standards. 2) Islamic private universities carries out the vision, mission of the National Higher Education in accordance with University permission and Study Program permission determined by the Minister of Education Implementation, 3) Islamic private universities has been in accordance with the requirements held by the government, 4) The funding used has been reported every year 5) Financial Statements have been audited by the Public Accounting Firm, 6) Implementation of education is delivered to the Minister, and the foundation (organizing body) in annual report, 7) Summary of the Islamic private universities Annual Report is announced annually to the public.

Vertical accountability can be measured by indicators - 1) Higher education responsibilities morally and spiritually for all activities of Tri Dharma activities., 2) University carry out the responsibilities written in the Vision and Mission as a form of responsibility to Allah swt, 3) Vision and Mission this illustrates the Islamic world view used by University in carrying out its vision and mission.
Fourth: Quality assurance and relevance - The quality of education determines the success of Islamic private universities in achieving the stated Vision and Mission. Increasingly high demands from the market as a user of graduates, the development of University that increasingly lead to technology, as well as other opportunities, make university must be able to implement internal controls in order to be able to deal with various threats by utilizing existing opportunities.

Therefore, after Islamic private universities is demanded to be able to implement Independence, then Fairness (treats fairly to stakeholders), must be accountable in fulfilling information needs as vertical and horizontal responsibilities, and the fourth must be able to apply the principles in the effectiveness of internal control in order to achieve good quality education. This dimension can be achieved through an internal quality assurance system, treasure study, the student feedback to the institution, the role of Alumni in the development of the institution, and a survey of the services (Kim, 2008). These indicators can be used to assess the dimensions of quality assurance and relevance in Islamic university governance.

Fifth: Effectiveness and Efficiency - After fulfilling the dimensions of independence, fairness, accountability, quality assurance and relevance, Islamic private universities must be able to carry out effective and efficient planning functions. Indicators of achieving this functional planning are seen from the existence of a planning system both long term, and short term (annually).

Islamic private universities must have a planning document that describes the ability in planning both long-term activities and short term activities either in the form of strategic plans or other documents that can be used as a reference for all units in the University in carrying out its duties and authority, as well as an evaluation tool for the planning that has been carried out. These dimensions are in the order of priority levels which are not so urgent, because in general Islamic private universities has owned and implemented an effective and efficient planning system.

Sixth: Responsibility - Islamic private universities accept responsibility for managing resources from 
the founder's whether foundations and other forms of legal entity. This dimension is the sixth priority sequence in eight dimensions of the dimension in Islamic University Governance. Islamic private universities are responsible for managed resources. The responsibilities of University are reflected in the responsibilities of each section of the tertiary institution. This dimension can be measured by the responsibility of each individual for all actions in accordance with the predetermined job description, fulfillment of lecturers' compliance with the University ethical values and norms, the division of positions, functions, tasks, responsibilities and authorities of each element of organization, standard operating procedure (SOP) for each activity, competency-based career system and track record, the right merit system (incentives and dis-incentives) for employees.

Seventh: non-profit Oriented - As an institution of higher education that has an educational function, the mandate of Islamic private universities is the nature of the business of Islamic private universities that are not profit oriented. The collection of funds obtained through the government, students and other institutions must be utilized to improve the University quality and development. This dimension can be measured by the budget used to improve the quality and development of University. Effectiveness and clarity of the budget is one of the tools for planning, as well as evaluation in the development of University, and indicators for assessing the use of collected funds allocated for the University development.

Eighth: Transparency - The transparency dimension is the final dimension in the measurement of Islamic university governance. Transparency is the level at which the university's operational activities can be accepted and understood by stakeholders (information disclosure). This indicator can be assessed by a check and balance mechanism as a mechanism in Tabayun, a control function by the senate to the Rector and the Dean, the implementation of Islamic private universities Vision and Mission in accordance with Islamic values.

\section{CONCLUSION:}

Based on these results, it can be concluded, that the measurement of Islamic University Governance with eight dimensions and 35 indicators. The order of UniversePG I www.universepg.com importance is dimension, namely the dimension of independence, then fairness, accountability, quality assurance and relevance, effectiveness and efficiency, responsibility, nonprofit, and transparency. Based on the research findings, future research needs to develop a more comprehensive indicator of Islamic University governance by considering government regulation, market demand and needs for financial statement information, in order to obtain comprehensive measurement indicators for assessing Islamic University Governance.

\section{ACKNOWLEDGEMENT:}

First, I am grateful to Allah (SWT). I am grateful to YBWSA Foundation and UNISSULA who funded this research, and colleagues who support the completion of this research.

\section{CONFLICTS OF INTEREST:}

The authors declare that there are no conflicts of interests to this research.

\section{REFERENCE:}

1. Alam CM and Ziaul HM. (2006). The Basic Theory of Corporate Governance in Islamic Perspective, Corporate Governance, 6(2), 116-128. https://doi.org/10.1108/14720700610655132

2. Ali DY, Umar A, and Mohammed SAR. (2016). A Conceptual Study on Islamic Corporate Governance Model in Curtailing Bank's Fraud, International Journal of Economics, Finance and Management Sciences, 4(6), 357-361. https://doi.org/10.11648/j.ijefm.20160406.17

3. Al Quran, Surah Fussilat's, 30-31.

4. Al Quran, Surah Annisa 58.

5. Al Quran, Surah Al Anfal 27.

6. Al Quran, Surah Al Baqarah 2: 22.

7. Dirwan A. (2012). High quality colleges are part of the concept of self-reliance.

8. Elfindri E. (2016). Healthy University. Kompas, 4 March 2016.

9. Fatin FH, Sri I, Hartutik, and Dwi SR. (2017). Islamic Model of Corporate Governance at the Islamic Boarding School, Journal of Business and Economics Review. 2(1), 56-63.

10. Gazi MAI. (2020). Islamic Perspective of Leadership in Management; Foundation, 
Traits and Principles, Int. J. Manag. Account. 2(1), 1-9.

https://doi.org/10.34104/ijma.020.0109

11. Imran HN, Shazia A, Syed AHZ and Kashif R. (2011). The model of good governance in Islam, African Journal of Business Management, 5(27), 10984-10992. https://doi.org/10.5897/AJBM10.1416

12. Islam MT, and Alam MJ. (2019). The Relationship between Informal Economy and GDP Growth: A Study on South-Asian Developing Countries. Can. J. Bus. Inf. Stud., 1(5), 01-09. https://doi.org/10.34104/cjbis.019.0109

13. Jony MTI, Alam MJ, Amin MR, and Alam MJ. (2019). The Impact of Autocratic, Democratic and Laissez-Faire Leadership Styles on the Success of the Organization: A Study on the Different Popular Restaurants of Mymensingh, Bangladesh, Can. J. Bus. Inf. Stud., 1(6), 28-38. https://doi.org/10.34104/cjbis.019.028038

14. Kim T. (2008). Changing University Governance and Management in the UK and Elsewhere Under marker Condition, Issue of Quality Assurance and Accountability, Intellectual Economics, 2(4), 35-42.

15. Media Indonesia (2010). Becoming a reliable university in the Digital Era.

16. Milon M., (2019). Present scenario of human resource management (HRM) practices in the life insurance companies:
Bangladesh perspective. Can. J. Bus. Inf. Stud., 1(6), 17-27.

https://doi.org/10.34104/cjbis.019.01727

17. Ninik FY, and Ilsa HS. (2015). Internal Control and Risk Management in Ensuring Good University Governance, Journal of Education and Vocational Research. 6(2), 612.

18. Quyen, DTN. (2014). Developing university governance indicators and their weighting system using a modified Delphi method, Proceeded, Social and Behavioral Science, 141: 828-833.

https://doi.org/10.1016/j.sbspro.2014.05.144

19. Shuvro RA, Saha S, and Alam MJ. (2020). Measuring the level of Job Satisfaction of the Employees of Grameen Bank: An Empirical Study, Can. J. Bus. Inf. Stud., 2(1), 1-11. https://doi.org/10.34104/cjbis.020.01011

20. Siri M. (2015). The concept and orientation of Muhammadiyah's College graduate Program, Excellence and uniqueness.

21. Sita YS, Amiruddin T, Chalid IM. (2017). The Implementation of Good University Governance in the Private Universities in Makassar (Indonesia), 39(2), 1-13.

22. Sumarni S. (2009). Good University Governance and the implications of the development of the study Program of Islamic Religious education, Tarbiyah, UIN Sunan Kalijaga Faculty. 6(1), 175-194.

Citation: Apriyanti HW. (2020). Measurement and assessment of the developmental status of Islamic University governance: Indonesia perspective, Int. J. Manag. Account. 2(1), 10-21.

https://doi.org/10.34104/ijma.020.10021 @) @ 